\title{
Työntekijä itsensä johtajana työelämäoppaissa
}

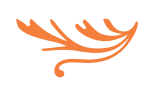

Työelämässä menestyminen kuvataan työelämäoppaissa henkilökohtaisena projektina, joka edellyttää työntekijältä itsensä johtamista ja muokkaamista. Tässä projektissa onnistuminen vaatii työntekijältä tahtoa ja kykyä jatkuvaan kehittymiseen.

甲 ARTIKKELISSA TARKASTELEMME yhtä oman elämän hallintaan keskittyvän self-help -kirjallisuuden alalajia eli kirjoja, joiden tavoitteena on neuvoa lukijoitaan saavuttamaan menestystä työelämässä. Kutsumme näitä teoksia työelämäoppaiksi. Työelämäoppaiden, kuten koko self-help -kirjallisuuden merkitys, näkyvyys ja markkinat laajentuvat kaiken aikaa. Yksin Yhdysvalloissa self-help -kirjallisuuden kasvun on sanottu pitävän pystyssä muutoin hiipumassa olevaa kirjakustannusalaa (McGee 2005, 11-12).

Nykyisessä työelämässä omien taitojen jatkuva kehittäminen on arkipäivää, etenkin asiantuntijatehtävissä toimivilla työntekijöillä. Työssä kehittyminen voidaan kokea jopa yhdeksi työn mielekkyyden ja työhön sitoutumisen edellytykseksi, joskin samaan aikaan se voidaan kokea myös haasteeksi. (Saari 2014.) Työelämäoppaat eivät kuitenkaan keskity minkään työn sisällölliseen osaamiseen, vaan työntekijän työroolin, työasenteen ja työtapojen kehittämiseen. Työtaitojen sijaan muokkaamisen kohteena ovat työntekijyys ja työntekijän subjektiviteetti.

Yksi työelämän suurista muutoksista on työn subjektivoituminen, jolla viitataan työn riippuvuuteen tekijästään ja hänen subjektiviteetistaan (Julkunen 2008). Analysoimme, millaisena subjektina työntekijä nähdään työelämäoppaissa ja millaiseksi subjektiksi 
hänen pitäisi tulla menestyäkseen tai selviytyäkseen työelämässä.

Aluksi luomme katsauksen self-help -kirjallisuuteen sekä työelämäoppaisiin osana tätä lajityyppiä. Sitten tarkastelemme suomalaisen työelämän muutosta ja työn subjektivoitumista. Lisäksi tarkennamme tutkimuksen teoreettista viitekehystä, jonka muodostavat keskustelut työn subjektivoitumisesta, minätekniikoista ja alaistaidoista. Sen jälkeen esittelemme tutkimuksen aineiston ja aineiston lukutavan, ja siirrymme aineiston analyysiin. Viimeisenä pohdimme tutkimuksen tulosten merkitystä.

\section{ELÄMÄNHALLINTA, ITSEAPU JA TYÖELÄMÄ}

Työntekijöiden työelämässä selviytymistä tukevat opaskirjat ovat osa laajaa self-help -kirjallisuuden genreä. Self-help -kirjallisuus on populaarin kirjallisuuden lajityyppi, jonka lähtökohtana on ihmisten tarve hallita ja muuttaa elämäänsä. Alan klassikkona voidaan pitää Dale Carnegien teosta Miten saan ystäviä, menestystä, vaikutusvaltaa vuodelta 1937. Kirjaa on myyty miljoonia kappaleita eri kielillä ja siitä on tehty useita käännöksiä myös suomeksi. Self-help -kirjallisuudelle ei ole vakiintunutta suomenkielistä nimitystä. Käsitteen suora käännös on itseapu tai oma-apu, jotka kuulostavat varsin kankeilta. Niinpä suomeksikin käytetään usein englanninkielistä termiä, kuten mekin tässä artikkelissa teemme.

Self-help -kirjallisuus voidaan sijoittaa itsensä kehittämiseen liittyvän kirjallisuuden alalajiksi ja osaksi self-help -teollisuutta, joka tähtää erilaisiin muodonmuutoksiin ja elämänhallintaan (Alasuutari 2012, 16; McGee 2005, 11). Työelämässä menestymiseen keskittyvässä self-help -kirjallisuudessa auttamisen kohteena ja toimijana on aina yksilö - kuvitteellinen kirjaa lukeva työntekijä - kokonaisen työpaikan tai organisaation sijaan.

Organisaation toimintatapoihin vaikuttaminen voi olla työntekijän toiminnan motiivi, mutta työelämäoppaat on lähtökohtaisesti kirjoitettu yksittäiselle työntekijälle, joka pyrkii ajatteluaan, asennettaan tai toimintaansa muuttamalla sopeutumaan työelämän haasteisiin. Itsensä kehittäminen työelämä- ja muiden self-help -oppaiden avulla voidaan nähdä myös osana uudenlaista työelämää, jossa työntekijä kehittää osaamistaan koko työuransa ajan (Saari 2013).

Työelämäoppaiden tyylilajiin kuuluu kirjojen myyvä ja paljon lupaava nimeäminen. Yhteistä niille on paitsi muutoksen lupaaminen, myös muutoksen nopeus ja pysyvyys. Tunnusomaista on lisäksi lupaus muutoksen helppoudesta sekä siitä, että lukijalle tarjotaan käytännönläheisiä neuvoja muutoksen saavuttamiseksi. Esimerkiksi teos Rework: Change the way you work forever (Fried \& Heinemeier Hansson 2010) lupaa paitsi muutosta, myös muutoksen kestävän koko loppuelämän. Kirjat voivat myös luvata auttaa työn kestämisessä muuttamatta itse työtä. Näin lupaa teos How to Be Happier in the Job You Sometimes Can't Stand: Twelve Keys to Being Happier in Your Job (West 2014).

Pohjoisamerikkalainen työkulttuuri on erilainen kuin suomalainen, joten kaikki oppaat eivät ole suoraan sovellettavissa Suomeen. Esimerkiksi teoksessa Why Work Sucks and How to Fix it (Ressler \& Thompson 2008) esitetään mullistavana uudistuksena siirtyminen kokonaistyöaikamalliin. Tällöin työpaikalla vietetyn ajan sijaan seurataan työn tuloksia. Tämä työaikamalli on Suomessa käytössä etenkin toimihenkilöaloilla, joten suomalaiseen keskusteluun tai työelämän arkeen se ei tuo juurikaan uutta.

Suomessa työelämäoppaiden historia on lyhempi kuin Yhdysvalloissa. Suomalainen tuotanto on kasvanut 2000-luvulla, muun itseapukirjallisuuden suosion kasvun myötä. Suomalaisen self-help -kirjallisuuden valikoima on suhteellisen laaja, ja myös työelämäoppaita on paljon. Osa niistä keskittyy työn organisointiin tai yrityksen kaupalliseen kannattavuuteen.

Se osa, josta artikkelissamme olemme kiinnostuneita, keskittyy työntekijän ominaisuuksien, asenteiden ja taitojen kehittämiseen. Taidoilla ei tässä tarkoiteta työn sisältöön kuuluvaa osaamista, kuten sairaanhoitajan taitoa antaa injektio, tai tilastotieteilijän kykyä käyttää analyysiohjelmaa, vaan työssä olemisen, työhön asennoitumisen ja työn hallinnan taitoja.

Self-help -kirjojen kirjoittajat asettuvat auktoriteeteiksi, jotka kertovat lukijalle, millä keinoin hänestä voi tulla aiempaa parempi työntekijä, tai työntekijä, jolla on aiempaa parempi olo. Yhdysvaltalaisessa traditiossa työelämäoppaiden kirjoittajien auktoriteettia 
nostetaan usein titteleillä ja korostamalla korkeaa koulutusta (Dolby 2008, 8). Suomessa tekijät ovat usein työelämän tutkimuksen, psykologian, median, kaupallisen alan tai johtamisen ammattilaisia. Taustastaan riippuen tekijät perustavat näkemyksensä joko omaan työuraansa, johtamiskokemukseensa tai asiakkaidensa kokemuksiin, tai näihin kaikkiin yhdessä.

Suuresta suosiostaan huolimatta self-help -teollisuutta ja -kirjallisuutta on myös kritisoitu. Oppaat nähdään tehottomiksi puoskareiden tuotteiksi, joihin hyväuskoiset ihmiset tuhlaavat rahansa (esim. Tiede 2001). Lisäksi oppaiden esitetään perustuvan hyperindividualismiin ja unohtavan sosiaalisuuden, jolloin yksilö on vastuussa itsestään ja itsensä kehittämisestä, mutta ei muista (Rimke 2000). Kritiikistä huolimatta uusia alan kirjoja ilmestyy jatkuvasti. Ne saavat näkyvyyttä myynti- ja lainaustilastojen lisäksi mediassa. Työelämäoppailla on merkittävä sija osana myös suomalaista yhteiskuntaa, joten on perusteltua tarkastella analyyttisesti, mitä ja miten niissä opastetaan.

\section{TYÖN SUBJEKTIVOITUMINEN JA ALAISTAIDOT}

Suomalainen työelämä kuvataan usein etenkin mediassa kovaksi, haastavaksi ja hallitsemattomalla nopeudella muuttuvaksi. Myös tutkimuskirjallisuudessa (esim. Siltala 2004) työtä on kuvattu elämänosana, joka tuottaa pikemminkin pahoinvointia kuin hyvinvointia.

Yksi suurista työelämän muutoksista on työn subjektivoituminen ja yksilöllistyminen. Työstä on tullut yksittäisten työntekijöiden henkilökohtainen projekti, jonka onnistumisesta heidän on kannettava vastuuta sen sijaan, että vastuu olisi työorganisaatioilla. Työ on siis subjektivoitunut niin, että työntekijää pyydetään käyttämään osaamistaan, taitojaan, tunteitaan ja motivaatiotaan, osallistumaan päätöksentekoon sekä vastuunjakoon ja tekemään tämä toisten kanssa kommunikoiden. (Julkunen 2008; Thrift 2005.)

Michel Foucault'a (2010) seuraten subjektivoituminen voidaan nähdä minätekniikkana, jonka avulla yksilö luo suhdetta itseensä ja muokkaa omaa toimintaansa. Subjektivoituminen on kurin ja kontrollin sisäistämistä niin, että yksilö kokee velvollisuudekseen noudattaa sitä. Työn subjektivoitumisen myötä työntekijää ei kontrolloida yksinomaan ulkoisesti, vaan kontrollin kohteeksi asetetaan myös työntekijän mieli ja kontrolloijaksi työntekijä itse (Rose 1989). Työnantaja ei sano millainen työntekijän pitäisi olla ja miten toimia, vaan työntekijän on ymmärrettävä se itse ja toimittava sen mukaisesti.

Suomalaisen työelämän voi silti sanoa, muutoksistaan huolimatta, tuottavan edelleen tekijöilleen myös hyvinvointia (Alasoini 2010). Myös kansainvälisissä vertailututkimuksissa suomalaisen työelämän laadun on todettu olevan yhtä korkealla kuin muissa Pohjoismaissa (Hartikainen ym. 2010). Samalla on nostettu esiin henkilökohtaisen työasenteen merkitys työn mielekkyydelle. Tästä yksi esimerkki on MarjaLiisa Mankan (2013) esittelemä työn ilon käsite. Positiivisen psykologian suuntaus näkyy työelämäntutkimuksessa, ja esimerkiksi työn imu (Hakanen 2005) on noussut merkittäväksi tutkimuskohteeksi. Myönteinen ajattelu ja itsensä kehittäminen eivät ole yksinomaan populaarien työelämäoppaiden aiheita, vaan myös akateemisen tutkimuksen kiinnostuksen kohteita. Itsensä kehittämisen on havaittu olevan olennainen osa esimerkiksi työelämävalmennusta, jossa huomio on työntekijän eikä työpaikan kehittämisessä (Mäkinen 2013).

Työelämäoppaiden näyttämönä on jatkuvasti uudistuva työelämä, jossa työntekijöiden on suoriuduttava hyvin erilaisissa olosuhteissa. Suomalaisten työhön ja organisaatioon sitoutuminen on ollut perinteisesti hyvin vahvaa (esim. Jokivuori 2002). Niinpä työelämäoppaiden suosion taustalla saattaa olla työntekijöiden halu välttää työorganisaation vaihtaminen, ja siksi he etsivät sekä keinoja suoriutua työstään paremmin että välineitä sopeutua työn vaatimuksiin.

Aktiivista oman työsuorituksen parantamista, hallintaa ja suunnittelua on kuvattu alaistaitojen käsitteellä. Alaistaidoilla tarkoitetaan käytännössä toimintaa, joka ei kuulu muodollisten työtehtävien märïttelyyn tai ole osa ammatillista osaamista, vaan suuntautuu työpaikan kehittämiseen, viihtyvyyteen ja yhteistyöhön. (Keskinen 2005.) Alaistaidot ovat siis juuri se osa työtä ja työntekijyyttä, jonka kehittämiseen työelämäoppaat keskittyvät.

Tämän teoreettisen taustan pohjalta tarkastelemme analyysissämme työelämäoppaiden työntekijälle 
tarjoamia kehittymisen suuntia ja tapoja. Uuden talouden teoretisoinneissa on keskusteltu uudenlaisen työntekijäsubjektin muotoutumisesta. Työelämän subjektivoitumisen seurauksena työntekijän on jatkuvasti kehitettävä alaistaitojaan. Hänen on tarkkailtava itseään työntekijäsubjektina sekä itsensä johtajana pärjätäkseen työssään ja tehdäkseen työpaikastaan sellaisen, jossa työskentely on mielekästä. Jäljitämme tätä subjektia, hänen ominaisuuksiaan ja taitojaan työelämäoppaista, jotka tarjoavat tähän hetkeen perustuvan mutta samalla tulevaisuusorientoituneen kuvan suomalaisesta työelämästä.

\section{AINEISTO JA MENETELMÄT}

Aineistonamme on kolme suomenkielistä työelämäopasta. Käännöskirjat olemme rajanneet aineiston ulkopuolelle, koska katsomme, että suomalaisen työelämän ja -markkinoiden erityispiirteet tulevat paremmin esiin suomalaisille kirjoitetuista kirjoista. Vaikka esimerkiksi yrityskulttuuri on kovaa vauhtia yhtenäistymässä kansainvälisesti, on työelämän arjessa edelleen kansallisia eroja. Lisäksi olemme rajanneet aineiston ulkopuolelle kirjat, joiden kohteena on kokonaisvaltainen persoonallisuuden tai asenteiden kehittäminen tai elämänhallinta laajana tavoitteena. Rajaamme pois myös pelkästään johtamista tai esimies-alaissuhdetta käsittelevät teokset sekä työyhteisön vuorovaikutuksen parantamiseen keskittyvät kirjat.

Olemme sisällyttäneet aineistoon keskenään erilaisia työelämäoppaita, jotka keskittyvät erilaisiin teemoihin ja jotka on suunnattu eri työntekijäryhmille. Olemme kiinnittäneet aineiston valinnassa huomiota siihen, että oppaissa kehittämisen kohteena on niin työntekijän persoona, tunnetilat kuin työn organisointi. Aineiston rajaaminen kolmeen oppaaseen antaa mahdollisuuden keskittyä niiden teemoihin sekä keskinäisiin eroihin ja yhtäläisyyksiin yksityiskohtaisesti.

Analysoimme valittuja kolmea kirjaa esimerkkeinä työelämäoppaista, emme kattavana tai yleistettävissä olevana otoksena. Vaikka käsittelemme self-help -oppaita omana kirjallisuuden lajinaan ja työelämäoppaita sen alalajina, tarkoituksena ei ole tehdä genretutkimusta kirjallisuuden tutkimuksen näkökulmasta, vaan analysoida teoksia osana laajempaa työelämäkeskustelua.

Ensimmäinen aineistomme teos on Ilona Rauhalan (2011) Uskalla! Nainen työelämässä. Kirja keskittyy naisten työuran eri vaiheisiin, alkaen uran rakentamisesta omien vahvuuksien tunnistamiseen ja kehittämiseen sekä ajanhallintaan. Kirjassa Rauhala esitellään psykologiksi ja henkilökohtaiseksi valmentajaksi.

Toinen aineistomme teos on Pauli Aalto-Setälän ja Mikael Saarisen (2014) Innostus. Myötämanipuloinnin aakkoset. Kirjan lähtökohtana on ajatus innostuksesta keskeisenä työelämän liikkeellepanevana voimana ja työhyvinvoinnin lisääjänä. Kirja sisältää myös "myötämanipulointiharjoituksia" eli pieniä käytännön tehtäviä, joiden tarkoituksena on lisätä innostuneisuutta tai sen edellytyksiä esimerkiksi naurujoogan ja erilaisten tietoisuusharjoitusten avulla.

Kolmas analysoimamme teos on Saku Tuomisen ja Pekka Pohjakallion (2012) Työkirja. Työelämän vallankumouksen perusteet. Teos keskittyy työn organisoinnin parantamiseen ja sitä kautta työnteon mielekkyyden lisäämiseen. Kirja pohjautuu 925 - Redesigning the work week -hankkeeseen. Projekti tähtäsi perinteisen työaika-ajattelun sekä työn ja vapaa-ajan rajaamisen romuttamiseen, hyvinvointia ja oman elämän hallintaa korostaen. Teos sisältää harjoituskirjan eli sen tavoitteena on olla käytännönläheinen opas.

Analysoimme aineistoa lukemalla sitä artikkelin kysymyksenasettelun kannalta merkityksellisten käsitteellistysten läpi. Alun perin analyysimme lähti liikkeelle sen ihmettelystä, miten työelämäoppaita pitäisi lukea ja ymmärtää tutkimuksellisesta näkökulmasta. Tekstiaineistojen tulkinnassa ei ole ehdotonta kaavaa, joten niitä voidaan tulkita erilaisissa konteksteissa, mutta analyysin tulee aina pohjautua aineiston ehtoihin (Hyvärinen 2015, 16-21).

Oppaiden käsittely omana lajityyppinään auttaa hahmottamaan niiden tapaa jäsentää työelämää ja työntekijöiden toimintaa ja samalla osaltaan tekstuaalistaa sosiaalista todellisuutta (lajityypin käsitteestä tutkimuksessa ks. Aro, Alastalo \& Lempiäinen 2012). Päädyimme tulkitsemaan oppaita teksteinä, jotka luovat kuvaa sekä työelämästä että implisiittisesti myös oppaiden lukijoista sen sijaan, että keskittyisim- 
me pelkästään niiden antamiin neuvoihin. Tämän lukutavan kehyksessä kysymme, millaisena oppaat esittävät niiden lukijan, eli omaa työntekijyyttään ja osaamistaan kehittävän työntekijän. Lisäksi kysymme, millaiseksi lukijan tulisi oppaiden antamien ohjeiden avulla muuttua selviytyäkseen ja jopa menestyäkseen työelämässä.

\section{TYÖELÄMÄOPPAIDEN LUKIJOISTAAN}

\section{LUOMA KUVA}

Aineistomme oppaista yhdessäkään ei kerrota suoraan, millaiselle työntekijäjoukolle kirjat on suunnattu. Kuitenkin kirjoista voi päätellä, millaisina subjekteina lukijat nähdään. Yhteistä kaikille kirjoille on se, että niiden lukijat oletetaan työstään kiinnostuneiksi ja työssään ainakin jollakin tavalla viihtyviksi työntekijöiksi. Lisäksi lukijoiden odotetaan olevan työelämäoppaiden perusidean mukaisesti valmiita, halukkaita ja kykeneviä kehittämään itseään ja vaikuttamaan omaan työn tekemisen tapaansa. Toisin sanoen lukijat nähdään oppivina ja suhteellisen autonomisina työntekijöinä, jotka omaavat muutoksen edellyttämää potentiaalia. Samalla kuitenkin esitetään, että lukijan työtavassa on jotain häiritsevää, hallitsematonta tai kehitettävää, joka pitää ottaa haltuun itsensä johtamisen keinoin. Jonkinasteisen ongelman tai kehittämisen tarpeen kokeminen oletetaan siis motiiviksi työelämäoppaan lukemiselle.

Uskalla!-teos lähtee liikkeelle työntekijän sukupuolesta ja siihen liitetyistä oletuksista. Kirjan mukaan naisen perusolemus on "ihanuus", mikä jokaisen naisen pitäisi pitää mielessään "työelämän moninkertaisella maratonilla”.

"Jos lähdet tälle kestäryysmatkalle mielessäsi oma ihanuutesi, matkasta tulee ihana, kaunis, leikkisä ja miellyttävä" (s. 19).

Opas kehottaa lukijoita kääntämään selkänsä ikäville asioille ja pitämään mielessään oma ihanuutensa, mikä auttaa naislukijoita työelämässä. Vallanhaluinen ja aggressiivinen nainen puolestaan herättää kirjan mukaan ympäristössään vastenmielisyyttä (s. 146). Samanlaisia sukupuoleen perustuvia perusolemuksen määrittelyjä tai tunneilmaisun arviointeja ei aineistomme muissa, sekä miehille että naisille suunnatuissa kirjoissa esitetä.

Lisäksi Uskalla! kehottaa naisia tulemaan "hyviksi, suorastaan erinomaisiksi, mutta ei ehkä huipuiksi” (mt.). Näin lukija määritellään potentiaaliseksi menestyjäksi, jolla on mahdollisuudet edetä työelämässä. Rauhalan mukaan teos ei kuitenkaan ole kirjoitettu niille naisille, joille menestys tarkoittaa ylimpiä johtaja-asemia (s. 170-172). Tämä herättää kysymyksen, nähdäänkö kirjassa jotkin työtehtävät ja työn tekemisen tavat feminiinisemmiksi kuin toiset, jolloin kirja keskittyy pelkästään näihin alempiin, feminiinisiksi koettuihin positioihin.

Varpu Alasuutari on todennut, että monesti työelämäoppaissa naisten menestymisen mittariksi märïtellään raha. Usein näiden oppaiden kirjoittajien tausta on liike-elämässä, ja he kannustavat naisia pyrkimään tulosvastuullisiin tehtäviin, joissa pääsee tekemisiin rahan kanssa. Sen sijaan journalistiikan ja viestinnän parissa työskennelleiden kirjoittajien oppaissa menestystä ei ole sidottu yhtä selkeästi rahan tavoitteluun, vaan menestyksen määrittely riippuu yksilön henkilökohtaisista päämääristä. (Alasuutari 2012, 33-34.) Uskalla! lukeutuu jälkimmäisiin oppaisiin. Myös Työkirjassa ja Innostus-kirjassa menestys kuvataan rahan tavoittelua henkilökohtaisemmaksi ja moniulotteisemmaksi päämääräksi.

Innostus-teoksen perusajatus on olettamus, jonka mukaan lukija ei ole "tarpeeksi" innostunut työstään, mutta hän voi kehittyä innostuneeksi. Opas keskittyy innostuneisuuteen tunteena, toimintana ja persoonallisuuden tyyppinä, jota työntekijän pitäisi vahvistaa itsessään. Kirjan lähtökohtana on ollut esipuheen mukaan tekijöiden oman innostuksen hukkuminen ja sen tajuaminen, että innostuneisuus on tärkeä tekijä sekä yksilön työhyvinvoinnin että työn tuloksellisuuden kannalta (s. 9-10). Oppaan lukijat nähdään osin oppaan kirjoittajien kaltaisina, ainakin välillä innostuksensa hukanneina työntekijöinä. Innostuksen etsiminen ja löytäminen asettuu työntekijän vastuulle sen sijaan, että työnantajaa vaadittaisiin kehittämään ja organisoimaan työtehtävät niin, että työntekijät innostuisivat niistä. Työntekijän on itseään valvovana subjektina havaittava oma innostukseton tilansa ja pyrittävä muuttamaan itseään, ennen kuin siihen kehotetaan. 
Työkirja ja sen taustalla ollut hanke on suunniteltu asiantuntijatehtävissä työskenteleville lukijoille eli niille, joilla työ ja vapaa-aika tahtovat sekoittua ja joilla on myös mahdollisuus vaikuttaa työaikoihinsa. Kirjassa tätä työtä kutsutaan yksinkertaisesti toimistotyöksi (s. 12). Samalla todetaan, että sillä tarkoitetaan samaa kuin henkisellä työllä, tietotyöllä tai ideavetoisella työllä. Oppaan lähtökohtana on havainto, jonka mukaan tällaista työtä tekevät eivät voi erityisen hyvin työssään. Sen sijaan he uupuvat ja kokevat, etteivät he saa mitään aikaan. Tässä mielessä oppaan kuvaama lukija on siis hyvin samankaltainen kuin Innostus-kirjassa.

Työkirjassa pohditaan myös työn merkityksellisyyttä ja painotetaan, että "ihmiselle on erittäin tärkeää kokea, että omalla ja yrityksen toiminnalla on jokin suurempi merkitys" (s. 119). Teoksen mukaan ihmiset ovat kyllä yleensä ylpeitä siitä, mitä heidän työnantajayrityksensä tekee, mutta silti oma työ voidaan kokea sisällöttömäksi ja merkityksettömäksi. Työn merkityksellisyyden tuottaminen ja oivaltaminen ovat kirjan tavoitteita. Samalla käänteisesti tunne työn merkityksettömyydestä luo motiivin kirjaan tarttumiselle.

Kaikki kolme teosta liikkuvat subjektivoituneen työn ja sen edellyttämien alaistaitojen eri tasoilla. Uskalla!-oppaaseen on sisällytetty työntekijän koko elämänkaari: persoona, sukupuoli ja perhetilanne. Kirjassa kehittämisen kohteina ovat sekä koko henkilö että hänen työuransa.

Sekä Innostus-teoksen että Työkirjan fokus on Uskalla!-oppaaseen verrattuna kapeampi, sillä ne keskittyvät suoremmin työelämään, kuten lukijan asenteeseen ja suhtautumiseen työelämää kohtaan, sekä joiltain osin myös työn tekemisen käytäntöihin. Lukijan oletetaan kamppailevan työelämän hallinnan ja oman työntekijyytensä kanssa ja tarvitsevan siksi opastusta. Samalla oppaat on kohdistettu lukijalle, jolta voidaan odottaa minätekniikoiden edellyttämää itsekuria ja riskien hallintaa.

\section{TYÖELÄMÄOPPAIDEN TARJOAMAT AVAIMET MENESTYKSEEN}

Työelämäoppaiden perusidea on tarjota lukijalle neuvoja, miten toimia ja asennoitua, jotta voisi menestyä alati muuttuvassa työelämässä. Jokaisella oppaalla on lähtökohtanaan melko yksinkertainen muutos, jonka voi kiteyttää yhteen virkkeeseen. Muutoksen myötä lukija voi tulla entistä rohkeammaksi, innostuneemmaksi tai suhtautua koko työelämään toisella tavalla kuin ennen.

Uskalla!-teos kehottaa naisia olemaan rohkeita työelämässä. Kirjaa lukiessa törmää kuitenkin toistuvasti hyvinkin perinteiseen kuvaan naisesta työntekijänä ja äitinä, jonka mies tekee pitkää päivää edetäkseen urallaan ja huolehtiakseen perheen taloudellisesta hyvinvoinnista. Kuvan mukaan nainen on halunnut lapsia enemmän kuin uraa ja enemmän kuin mies. Äitiys on naisen työ, yhteiskunnallisesti yksi tärkeimmistä tehtävistä. Samanaikaisesti oppaassa todetaan, että naiset ovat saavuttaneet yhteiskunnallisen tasaarvon jo hyvän aikaa sitten. Tämä näkemys myötäilee postfeminististä ajatusta työelämästä (Alasuutari 2012). Tämänkaltainen kuvaus naisesta ja hänen paikastaan yhteiskunnassa, työelämässä ja perheessä on ristiriidassa uskaltamisen teeman kanssa, jos uskaltamisella tarkoitetaan jotakin uutta ja sovinnaisesta poikkeavaa. Samalla Uskalla!-opas sivuuttaa vaikeudet, joita sisältyy pienten lasten vanhempien työn ja perheen yhteensovittamiseen. Kaksi muuta opasta eivät juuri käsittele perhettä tai muita työelämän ulkopuolisia, niin kutsuttuja yksityisiä asioita, vaan niissä esiintyy pääosin sukupuoleton työntekijäsubjekti.

Kaikkia kolmea opasta yhdistävä teema on ajanhallinta työssä. Suhtautuminen aikaan ja uudenlainen ajankäyttö nostetaan oppaissa esiin osoituksena paremmista alaistaidoista. Uskalla!-teoksen mukaan:

"Kiire on vanhaa maailmaa. Rahan suoraviivainen ja itsetarkoituksellinen tavoittelu on vanhaa maailmaa. Tätä päivää on mielen ja energian hallinta!" (s. 42.)

Opas ei keskity rakenteisiin kiireen syynä tai esitä kiireen ratkaisuvaihtoehtona työn organisointia toisin. Sen sijaan ratkaisuna on kiireeseen ja työmäärään reagoiminen uudella tavalla. Tämä tapa on oppaan mukaan ihmisen sisäinen energia, jota tulisi johtaa ja hallita toisin kuin ennen.

Opas jakaa energian fyysiseen ja henkisen energiaan sekä ajattelun ja tunteiden energiaan. Työnteki- 
jän tulee siis kirjan mukaan seurata omaa energiatasoaan ja energian jakautumista näille eri alueille. Kirja ei kuitenkaan anna käytännön neuvoja, miten tämä tehdään. Oppaan anti onkin erilaisten energioiden tunnistaminen, mutta vastuu energian ylläpitämisestä ja käytöstä jää työntekijälle. Näin ollen työntekijän on käytettävä omia alaistaitojaan hallitessaan omia energioitaan ja organisoidessaan omaa työtään.

Myös Innostus-kirjassa puhutaan energiasta. Oppaassa esitetään, että innostus on energiaa, ja että innostus energisoi ihmisiä. Innostus siis mahdollistaa aiempaa paremman ajankäytön työn tehostamisen avulla. Oppaissa mainittu energia ei suoraan palaudu luonnontieteiden käsitykseen energiasta tai työntekijän mitattavissa olevaan vireystasoon, vaan siihen sisältyy ajatus jonkinlaisesta sisäisestä energiasta. Myös Innostus-teoksen mukaan työelämässä menestymisen salaisuus piilee nimenomaan työntekijän identiteetissä, jota tulee siksi kehittää oppaan tarjoamien minätekniikoiden mukaisesti.

Uskalla!- ja Innostus-oppaista poiketen Työkirjassa työntekijän kehitystavoitteena ei ole tunteen tai tunnetilan muuttaminen työssä. Sen sijaan tavoitteena on hallita työaikaa uudella tavalla, kun ensin on lopetettu ajan jaottelu työaikaan ja vapaa-aikaan.

Kirjan lähtökohtana on ollut työajan uudelleenajatteluun keskittynyt hanke. Työaika ja sen hallinta eivät ole vain ylhäältä alaspäin toteutettava työn organisoinnin kysymys, vaan työntekijän henkilökohtainen kehittämiskohde eli osa alaistaitoja. Työkirjassa ajankäyttöön otetaan kantaa esittelemällä lukijoille malli, joka on "avain ajatustyötä tekevän ihmisen nykyistä parempaan työviikkoon. Sen tavoitteena on auttaa meitä saamaan enemmän aikaan, mutta samalla väsymään vähemmän." (s. 209.)

Uskalla!-kirjan tavoin Työkirja ei ota kantaa työelämän kiireeseen sinänsä vaan opastaa lukijalle, miten kiireen kanssa voi elää ja tulla toimeen työtapoja muuttamalla. Työkirjassa kiire otetaan lähtökohtana, jota ei voi muuttaa: "(kiire) ei ole kenenkään vika. Sille ei voi tehdä mitään. Se on annettu asia. Se vaan on." (s. 48.)

Kirjat sivuuttavat myös sen, että kiire työssä tarkoittaa usein eri asioita naisille ja miehille. Heiskanen kumppaneineen (2006, 118-120) on esittänyt, että naisille kiire on työn paineisuutta ja sitä, että ei ole mahdollisuutta pitää taukoja työpäivän kiireen keskellä, kun asiakkaat tai kollegat odottavat. Sen sijaan miehille kiire ilmenee usein työajan venymisenä ylitöiksi.

Innostus-teoksen mukaan meidän kulttuuriperimämme estää innostumisen, eikä innostuksen näyttämistä pidetä aina suotavana. Oppaan mukaan tähän olisi saatava muutos. Kirjan esimerkkeinä esitellyt henkilöt edustavat innostuvia ja innostavia persoonia. Mukana ovat muiden muassa tosi-tv-tähti Arman Alizad ja kapellimestari Atso Almila. Innostuminen on tekijöiden mukaan paitsi sisäsyntyistä, myös opittava taito: "Hyvä tavoite myös innostumisen taidolle on holtiton määrä toistoja" (s. 52).

Työntekijän tulisi siis jalostaa omaa innostumisen taitoaan. Näin ollen työssä ja työstä innostuminen ei ole organisaation tai johtajien käsissä tai ylhäältä alaspäin annettua, vaan työntekijän itsensä kehittämisen tehtävä. Työntekijän tulee olla innostunut sekä kykenevä innostumaan ja innostamaan muita. Näiden ominaisuuksien kehittäminen ja niissä onnistuminen, eli alaistaitojen kehittäminen, on työntekijän itsensä vastuulla.

Innostus lähtee oppaan mukaan liikkeelle jo varhaisista vuorovaikutussuhteista (s. 31) ja temperamentista (s. 38), mutta siihen vaikuttavat myös opitut taipumukset (s. 42). Innostusta voi herätellä kehittämällä tietoisuustaitoja, eli opettelemalla vaikkapa tietoista läsnäoloa ja sen avulla suhtautumaan tilanteisiin uudella tavalla (s. 50). Tämän prosessin työntekijä joutuu sekä käynnistämään että läpikäymään itsenäisesti, koska "ratkaisu päänsisäisiin ongelmiin ei kerta kaikkiaan löydy pään ulkopuolelta vaan sen sisältä" (s. 52).

Innostus-teoksen toinen osa keskittyykin innostuksen ruokkimiseen sekä itsessä että myös muissa työyhteisön jäsenissä innostavan vuorovaikutuksen avulla. Tekijät esittelevät "myötämanipuloinnin positiivisen pyramidimallin". Siinä käsitellään esimerkiksi jännitteiden purkua, eleiden merkitystä kasvokkaisessa vuorovaikutuksessa kiinnostuksen osoittamiseksi, huumoria ja iloa työssä, sekä esitellään niihin liittyvät myötämanipulointiharjoitukset. Teos antaa kokonaisvaltaisen kuvauksen ongelmasta eli innostuksen puutteesta ja myös välineet ongelman ratkaisuun. Samalla se tulee kertoneeksi, että ratkaisu ei ole helppo, yksinkertainen tai nopea, vaan vaatii 
TYÖELÄMÄOPPAIDEN

\author{
MUKAAN VASTUU \\ TYÖEL ̈̈MÄÄN \\ SOPEUTUMISESTA \\ ON YKSINOMAAN \\ TYÖNTEKIJÄLL̈̈.
}

työntekijältä määrätietoista ponnistelua ja harjoittelemista.

Oppaiden esittelemään uudenlaiseen työntekijäsubjektiuteen sisältyy työntekijän nopeus, valppaus, innostus, joustavuus ja ketteryys. Näiden iskusanojen avulla oppaissa tehdään eroa vanhaan, oletettavasti paikalleen juuttuneeseen ja muutoshaluttomaan työntekijätyyppiin. Uuden työntekijän pitää olla hallittu subjekti. Osa tätä itsensä hallintaa on ymmärtää, että ei ole työntekijänä "valmis", vaan omat alaistaidot ovat vielä vajavaisia. Toisin sanoen työntekijä tunnistaa itsessään tarpeen muuttua sekä ajankohdan, koska muutos pitää toteuttaa. Ajankohdan ja muutoksen merkityksen oivaltaminen näkyy siinä, että lukija on ylipäätään tarttunut oppaaseen.

\section{TYÖELÄMÄ - HENKILÖKOHTAINEN KEHITYSPROJEKTI?}

Kolmessa analysoimassamme työelämäoppaassa työelämä nähdän henkilökohtaisena projektina, jota on suunniteltava ja hallittava niin, että se toimii yhä paremmin alati jatkuvien muutosten keskellä. Työntekijä nähdään autonomisena subjektina ja työelämän potentiaalisena uudistajana, joka ei ole riippuvainen muista ihmisistä eikä työelämän tai työpaikkojen rakenteista.

Oppaat sivuuttavat keskeisen kysymyksen siitä, mitä tehdä jos rakenteet sekä yhteiskunnan tasolla että omalla työpaikalla eivät mahdollista oppaiden esittämien muutosten toteuttamista. Siinä mielessä lukija esitetään lähes kaikkivoipana subjektina.
Emme voi tietää, ketkä näitä kirjoja lukevat ja millaisista syistä. Oletamme kuitenkin, että työelämäoppaat vastaavat johonkin tarpeeseen, johon esimerkiksi tutkimus ei pysty vastaamaan. Tutkimus on väistämättä suhteellisen hidasta reagoimaan muutoksiin ja trendeihin, eivätkä tutkijat voi tai halua antaa suoria toimintaohjeita työntekijöille.

Emme voi tietää, luetaanko kirjoja nimensä mukaisina itseapuoppaina, joiden opit ainakin jossakin määrin myös päätyvät käytäntöön. Oletamme kuitenkin, että lukijat reflektoivat kirjojen sisältöjä ja ohjeita suhteessa omaan työmarkkina-asemaansa ja toimintaansa, vaikka eivät kaikilta osin noudattaisikaan oppaiden neuvoja. Toisin sanoen oppaiden tarjoamat subjektivoitumisen minätekniikat voidaan omaksua tai niitä voidaan vastustaa. Oppaat antavat siten mahdollisuuden jatkuvaan itsensä kehittämiseen.

Vaikka työelämäoppaista saattaa olla apua yksittäisille henkilöille, on oppaisiin samalla suhtauduttava kriittisesti. Ongelmallista on se, että työelämäoppaat antavat kuvan, jonka mukaan vastuu työelämään sopeutumisesta on yksinomaan työntekijällä. Tällöin työelämältä laajalti sekä erityisesti yksittäisiltä työpaikoilta ja työyhteisöiltä ei edellytetä työelämän laadun kehittämistä. Ainoa muutoksen kohde on yksittäinen työntekijä. Tämä on työn subjektivoitumisen idean mukaista, mutta samalla varsin kapea näkemys työntekijöiden subjektiviteetista, joka on paljon muutakin. Se on ammattitaitoa, ammattiylpeyttä, osaamista, elettyjä kokemuksia, myönteisiä ja kielteisiä tunteita sekä sosiaalisia suhteita (Julkunen 2008, 164).

Työelämäoppaat kannustavat lukijoitaan kehittymiseen. Jotta kehittyminen on mahdollista, subjektivoituneessa työssä on otettava huomioon paitsi organisaatioiden, myös työntekijöiden itsensä kehittämistarpeet (myös Eteläpelto ym. 2014; Saari 2013). Edelleen, työn subjektivoitumisesta huolimatta ja juuri sen takia, organisaatioiden tulisi tarjota työntekijöilleen sellaiset olosuhteet, joissa työntekijöiden on mahdollista kehittää itseään ja tällä tavoin hyödyttää organisaatioitaan.

Työelämäoppaiden kirjoittaminen, kääntäminen ja julkaiseminen on merkittävää liiketoimintaa myös Suomessa. Oppaat osallistuvat keskusteluun siitä, millainen on tämän päivän työelämä ja miten työn- 
tekijöiden olisi syytä sopeutua siihen. Vaikka oppaat hyödyntävät tutkimustietoa joskus hyvinkin kevyellä tavalla, on niihin silti syytä suhtautua tutkimuksessa vakavasti. On tärkeää tulkita työelämäoppaiden sisältöä jo siitä yksinkertaisesta syystä, että niitä luetaan niin paljon. Vaikka olemme edellä keskittyneet hyvin rajattuun aineistoon, toivomme, että artikkeli toimii avauksena työelämäoppaiden tutkimukselle sekä keskustelulle niiden merkityksestä ja asemasta.

Tutkimusta on rahoittanut Suomen Akatemia (Flexlife-projekti, nro. 277376).

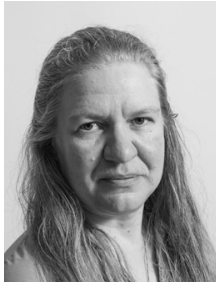

Tuija Koivunen tutkijatohtori Yhteiskunta- ja kulttuuritieteiden yksikkö Tampereen yliopisto

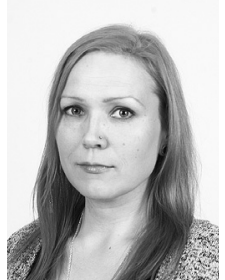

Tiina Saari tutkijatohtori Yhteiskunta- ja kulttuuritieteiden yksikkö Tampereen yliopisto 
Aalto-Setälä. P. \& Saarinen, M. (2014). Innostus. Myötämanipuloinnin aakkoset. Helsinki: Talentum.

Alasoini, T. (2010). Mainettaan parempi työ. Kymmenen väitettä työelämästä. EVA raportti. Helsinki: Taloustieto.

Alasuutari, V. (2012). Kynnysmatosta supernaiseksi? Postfeminismi ja menestys naisten työelämäoppaissa. Naistutkimuksen pro gradu -tutkielma. Tampere: Tampereen yliopisto.

Aro, J., Alastalo. M. \& Lempiäinen, K. (2012). Sosiologia. Teoksessa Heikkinen, V., Voutilainen, E., Lauerma, P., Tiililä, U. \& Lounela M. (toim.) Genre-analyysi. Helsinki: Gaudeamus.

Dolby, S.K. (2008). Self-Help Books: Why Americans Keep Reading them. Illinois: University of Illinois Press.

Eteläpelto, A., Vähäsantanen, K., Hökkä, P. \& Paloniemi, S. (2014). Miten käsitteellistää ammatillista toimijuutta työssä? Aikuiskasvatus 34(3), 202-214.

Foucault, M. (2010). Seksuaalisuuden historia. Tiedontahto, Nautintojen käyttö, Huoli itsestä. Toinen, uudistettu laitos. Helsinki: Gaudeamus.

Fried, J. \& Heinemeier Hansson, D. (2010). Rework: Change the way you work forever. Lontoo: Vermilion.

Hakanen, J. (2005). Työuupumuksesta työn imuun: työhyvinvointitutkimuksen ytimessä ja reuna-alueilla. Helsinki: Työterveyslaitos.

Heiskanen, T., Korvajärvi, P. \& Rantalaiho, L. (2006). Sukupuoli ja työ: Pysyvyyttä ja liikahduksia. Teoksessa Heiskanen, T., Leinonen, M., Järvensivu, A. \& Aho, S. (toim.) Kohti uutta työelämää? Tutkimuksen näköala työelämän kehitykseen. Tampere: Tampere University Press, 109-134.

Hyvärinen, M. (2015). Hajoavalla rannalla. Teoksessa Hyvärinen, M., Oinonen, E. \& Saari, T. (toim.) Hajoava perhe. Romaani monitieteisen tutkimuksen välineenä. Tampere: Vastapaino.

Julkunen, R. (2008). Uuden työn paradoksit. Keskusteluja 2000-luvun työprosess(e)ista. Tampere: Vastapaino.
Keskinen, S. (2005). Alaistaito - luottamus, sitoutuminen ja sopimus. Polemia-sarja, nro 59. Helsinki: Kunnallisalan kehittämissäätiö.

Manka, M-L. (2013). Työn ilo. Helsinki: Sanoma Pro.

McGee, M. (2005). Self Help, Inc: Makeover Culture in American Life. New York: Oxford University Press.

Mäkinen, K. (2013). "Itselleen voi sentään jotain" - itsen kehittäminen työelämävalmennuksessa. Aikuiskasvatus 33(4), 265-276.

Rauhala, I. (2011). Uskalla! Nainen työelämässä. Helsinki: Otava.

Ressler \& Thompson (2008). Why Work Sucks and How to Fix it. New York: Portfolio.

Rimke, H. M. (2000). Governing Citizens through SelfHelp Literature. Cultural Studies 14(1), 61-78.

Rose, N. (1989). Governing the Soul: The Shaping of the Private Self. Lontoo: Routledge.

Saari, T. (2013). Työssä kehittyminen tietotyöntekijän oikeutena ja velvollisuutena. Aikuiskasvatus 33(2), 95-106.

Saari, T. (2014). Psykologiset sopimukset ja organisaatioon sitoutuminen tietotyössä. Acta Universitatis Tamperensis 1944. Tampere: Tampere University Press.

Siltala, J. (2004). Työelämän huonontumisen lyhyt historia. Muutokset hyvinvointivaltioiden ajasta globaaliin hyperkilpailuun. Helsinki: Otava.

Tiede, T. (2001). Self-Help Nation: The Long Overdue, Entirely Justified, Delightfully Hostile Guide to the Snake-Oil Peddlers Who Are Sapping Our Nation's Soul. New York: Atlantic Monthly Press.

Thrift, N. (2005). Knowing capitalism. Los Angeles: Sage.

Tuominen, S. \& Pohjakallio, P. (2012). Työkirja. Työlämän vallankumouksen perusteet. Helsinki: WSOY.

West, R. (1998). How to Be Happier in the Job You Sometimes Can't Stand: Twelve Keys to Being Happier in Your Job. Dallas: Broadman \& Holman. 